\title{
PROGRAM OPTIMALISASI PERAN LABORATORIUM FISIKA SMA DI KOTA METRO
}

\section{Nyoto Suseno}

Universitas Muhammadiyah Metro

Riswanto *

Universitas Muhammadiyah Metro
ABSTRACT: THE ROLE OPTIMIZATION PROGRAM OF PHYSICAL LABORATORY OF SENIOR HIGH SCHOOL IN METRO CITY. The Government Regulation (PP) of the Republic of Indonesia no. 19 of 2005 sets eight educational standards. The results survey found every high school in Metro City has been equipped with physics laboratory and has formed an organizational structure. But the physics laboratory to support the learning process, has not been done well. The purpose of this lbM (Ipteks bagi Masyarakat) Program is to apply theory and concept of Laboratory management in order to optimize the role of Physics Laboratory to supporting the learning process. The methods used are: Making of laboratory inventory website, workshop of the standard making of laboratory management, facilitation of website and arrangement of laboratory apparatus, workshop of making work program, workshop of making service, and doing simulation result of the workshop. The results obtained are: 1) Generally the condition of high school physics laboratory in Metro City has exceeded the standard up to $71,9 \%$; 2) Aspects that do not meet government standards are no technicians and less on electric and sink socket facilities of $5,7 \%$; 3 ) Utilization of high school laboratory inventory website gives a quite effective and significant impact in assisting the administration of laboratory equipment and facilitate access in tracking the existence of physics laboratory equipment and materials.

KEYWORDS: IbM, Optimization, Physical Laboratory, Practical

* Corresponding Author: Fakultas Keguruan dan Ilmu Pendidikan (FKIP) Universitas Muhammadiyah Metro; Jalan K.H Dewantara No. 116, Metro Pusat, Iringmulyo, Metro Timur, Kota Metro, Lampung 34125, Indonesia; Email: riswanrumbia@gmail.com

Article History: Received: 11-07-2017; Revised: 01-12-2017; Accepted: 08-12-2017

Permalink: http://ppm.ejournal.id/index.php/pengabdian/article/view/28

How to cite (APA): Suseno, N., \& Riswanto. (2017). Program optimalisasi peran laboratorium fisika SMA di kota Metro. Jurnal Pengabdian Pada Masyarakat, 2(2), 149-158.

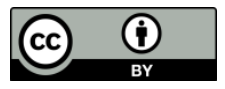

This is an open access article distributed under the terms of the Creative Commons Attribution 4.0 International License, which permits unrestricted use, distribution, and reproduction in any medium, provided the original work is properly cited. @ 2017, Nyoto Suseno, Riswanto.

\section{PENDAHULUAN}

Pemerintah telah menetapkan delapan standar pendidikan melalui PP RI No. 19 Tahun 2005 yang meliputi standar isi, standar proses, standar kompetensi lulusan standar, standar pendidik dan kependidikan, standar sarana dan prasarana, standar pengelolaan, standar pembiayaan dan standar penilaian. Berdasarkan 
Permendiknas Nomor 24 Tahun 2007, Laboratorium adalah salah satu standar sarana dan prasarana yang harus dipenuhi oleh setiap satuan pendidikan formal termasuk SMA. Karena itu melalui berbagai program pemerintah telah berupaya memenuhi kebutuhan laboratorium fisika SMA mulai dari gedung laboratorium, prasarana laboratorium, peralatan dan bahan laboratorium serta penyiapan sumberdaya manusia melalui pelatihan-pelatihan terhadap para guru tentang pengelolaan laboratorium. Dari enam SMA Negeri yang ada di Kota Metro, semua telah dilengkapi dengan sarana laboratorium fisika. Setiap Laboratorium fisika di SMA Negeri telah terbentuk tata kelolanya, terdiri dari satu orang kepala Laboratorium fisika dari jalur guru dan satu orang laboran.

Secara fisik dan kelembagaan SMA Negeri 1 Metro dan SMA Negeri 2 Metro, telah memiliki gedung laboratorium fisika, sarana-prasarana dan peralatan laboratorium fisika serta tata pamong pengelolaan laboratorium fisika juga telah terbentuk. Pengelola laboratorium fisika meliputi Kepala Laboratorium dan tenaga laboran. Namun demikian pemanfaatan laboratorium fisika di SMA Negeri 1 Metro dan SMA Negeri 2 Metro tersebut tidak dapat berjalan sebagaimana mestinya, bahkan laboratorium fisika belum dapat menunjang proses pembelajaran secara optimal.

Hasil survei terhadap keberadaan laboratorium fisika di SMA Negeri 1 Metro dan di SMA Negeri 2Metro menemukan beberapa kendala dan masalah dalam pengelolaan laboratorium fisika tersebut, yaitu: 1) kepala laboratorium hanya sebagai profesi sampingan, sedangkan profesi kepala laboratorium yang sesungguhnya adalah guru fisika, 2) tidak ada laboran yang mampu menguasai dan memahami berbagai alat laboratorium dan pekerjaan laboran, 3) minat dan motivasi guru untuk menggunakan laboratorium dalam pembelajaran kurang, 4) laboratorium tidak dikelola dengan baik, sehingga jika guru ingin menggunakan laboratorium fisika harus menyiapkan sendiri mulai dari perencanaan, penyiapan alat, penggunaan dan pengembalian serta penyimpanan alat, 5) alat-alat laboratorium fisika belum tersusun dengan baik, sehingga untuk mencari satu jenis alat saja diperlukan waktu dan curah tenaga yang cukup banyak.

Namun, terkait kendala teknis di SMA N 1 Metro karena adanya revitalisasi bangunan, sehingga program pengabdian yang dilakukan di sekolah tersebut di tunda hingga penyelesaian bangunan. Untuk itu tim pengabdian berinisiatif menambah sekolah mitra dengan melakukan survei di SMA N 5 Metro. Hasil survei yang diperoleh menunjukan bahwa sekolah tersebut tergolong sekolah yang baru didirikan, sehingga kepemilikan alat, bahan dan barang masih relatif baru dan jumlahnya cukup banyak. Secara rinci permasalahan yang dihadapi dalam 
pengelolaan laboratorium di SMA N 5 Metro terindikasi sama dengan sekolah mitra lainnya seperti tersebut pada paragraf sebelumnya.

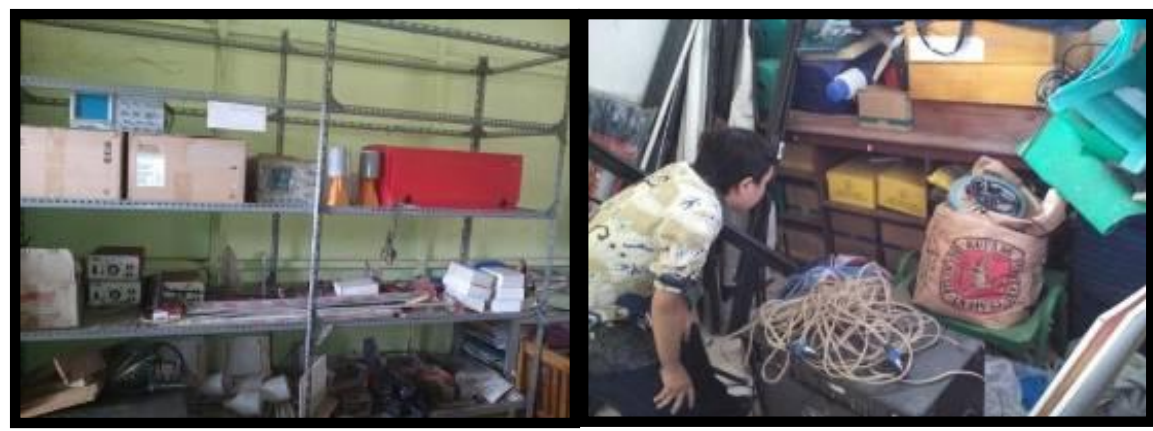

Gambar 1. Gambaran Kondisi Laboratorium di sekolah Mitra

Secara garis besar, mutu layanan dan pengelolaan sarana laboratorium fisika di SMA Negeri 1 Metro, SMA Negeri 2 Metro, dan SMA Negeri 5 Metro belum berjalan dengan baik dan optimal. Hal ini dikarenakan belum tersedianya sumberdaya manusia yang menguasai manajemen dan pengelolaan laboratorium, serta belum dikuasainya sistem pengelolaan laboratorium yang efektif dan efisien sehingga aplikatif. Standar pengelolaan laboratorium dan standar operasional prosedur (SOP) di ketiga SMA juga belum disusun, sarana-prasarana, alat dan bahan lab belum ditata dan diberi label, serta terdokumentasi dengan baik. Untuk itu maka perlu dilakukan program pengabdian masyarakat di SMA Negeri 1 Metro, SMA Negeri 2 Metro, dan SMA Negeri 5 Metro mengenai optimalisasi peran laboratorium fisika dalam menunjang proses pembelajaran di tiga SMA tersebut

\section{METODE PELAKSANAAN}

Ketiga sekolah mitra telah memiliki laboratorium fisika yang cukup, telah memiliki kepala laboratorium dan laboran, namun pemanfaatan dan pemberdayaannya belum optimal. Beberapa permasalahan mendasar dari tiga sekolah mitra adalah: 1) Tenaga pengelola laboratorium fisika belum memenuhi standar tenaga laboratorium sekolah sesuai Permendiknas Nomor 26 Tahun 2008, dimana pengelola laboratorium di ketiga sekolah mitra belum ada tenaga teknisi, yang ada baru kepala laboratorium dari jalur guru dan tenaga laboran yang bukan dari pendidikan khusus laboran, 2) SDM yang ada belum menguasai prinsip dan konsep pengelolaan laboratorium, 3) Belum memiliki standar pengelolaan laboratorium fisika, 4) Belum memiliki standar operasional pengelolaan (SOP) dalam pelayanan Laboratorium, 5) Belum memiliki program kerja, 6) Laboratorium fisika belum digunakan dalam mendukung proses pembelajaran. 
Solusi yang ditawarkan untuk mengatasi masalah sekolah mitra (SMA Negeri 1 Metro, SMA Negeri 2 Metro, dan SMA Negeri 5 Metro) adalah upaya lebih memberdayakan laboratorium fisika dalam mendukung proses pembelajaran fisika. Guna mengimplementasikan pengelolaan Laboratorium fisika tersebut, maka dilakukan beberapa langkah kegiatan sebagai berikut:

1) Mengupayakan melengkapi personalia Tenaga Laboratorium fisikasesuai standar tenaga laboratorium sekolah pada Permendiknas Nomor 26 Tahun 2008 oleh pihak Sekolah Mitra

2) Workshop dan pendampingan kepada tenaga laboran dalam menyusun dan mengadministrasikan alat dan bahan laboratorium fisika agar mudah diakses sesuai kondisi ruang lab dan alat-bahan yang dimiliki oleh Sekolah Mitra.

3) Workshop dan pendampingan kepada kepala laboratorium fisika dalam menyusun standar pengelolaan laboratorium fisika di sekolah mitra.

4) Workshop dan pendampingan kepada kepala laboratorium fisika dalam menyusun programkerja laboratorium fisika.

5) Workshop dan pendampingan kepada pengelola laboratorium fisika dalam menyusun SOP Pelayanan Laboratorium fisika.

6) Melakukan pendampingan dalam simulasi pengelolaan dan penggunaan laboratorium dalam mendukung proses pembelajaran fisika.

7) Melakukan pendampingan dalam implementasi program kerja laboratorium oleh pengelola laboratorium dalam melayani guru, siswa dan pengguna lainnya terutama dalam mendukung proses pembelajaran fisika.

8) Melakukan pendampingan terhadap kepala laboratorium dalam melaksanakan evaluasi dan pelaporan serta tindak lanjut

9) Melakukan pendampingan terhadap kepala sekolah dalam melaksanakan monitoring dan evaluasi dalam pengelolaan laboratorium fisika.

Setelah program kegiatan Ipteks bagi Masyarakat (IbM) berakhir, maka akan diperoleh SDM yang menguasai prinsip dan konsep pengelolaan laboratorium, diperoleh dokumen Standar pengelolaan laboratorium fisika, program kerja satu tahun dan lima tahun, SOP Pelayanan Laboratorium, dan pengalaman simulasi dalam pengelolaan laboratorium. Dengan demikian, maka diharapkan pemberdayaan Laboratorium fisika akan berkelanjutan dan berkembang dalam memaksimalkan fungsi dan peran laboratorium fisika di Sekolah Mitra untuk menunjang proses pembelajaran. 


\section{HASIL DAN PEMBAHASAN}

Program pengabdian ini merupakan program pemerintah melalui Ditlitabmas Kementerian Ristek-Dikti, yang dipercayakan kepada UM Metro. Guna memperlancar kegiatan dan komunikasi dengan pihak terkait, maka secara administrasi Lembaga Penelitian dan Pengabdian pada Masyarakat (LPPM) memohon izin kepada Kesbangpol dan Dinas Dikbudpora Kota Metro melalui surat Nomor 094/III.3.AU/F/LPPM/2016 tanggal 19 Maret 2016 dan kegiatan pengabdian ini telah mendapatkan izin dan rekomendasi dari Pemerintah Kota Metro melalui surat dari Kantor Kesbang dan Politik nomor: 070/59/LTD7.02/REG/2016 tanggal 18 April 2016 dan surat rekomendasi dari Dinas Pendidikan, Kebudayaan, Pemuda dan Olahraga Nomor: 070/839/D.3/0.3/2016 tanggal 29 April 2016.

\section{Pihak yang Dilibatkan dalam Kegiatan}

Kegiatan ini juga dipadukan dengan kegiatan PPLT yang melibatkan 4 (empat) dosen pembimbing lapangan dan 28 mahasiswa semester VII, dalam waktu selama 2,5 bulan. Dari pihak sekolah mitra kegiatan ini melibatkan sebanyak 6 orang guru dan 2 laboran.

\section{Pembuatan Website Invetaris alat, bahan dan barang Laboratorium}

Sistem inventarisir alat, bahan dan barang laboratorium dilakukan mengembangkan website inventaris Laboratorium. Hal ini sangat membantu pihak sekolah untuk memantau dan mencari keberadaan alat, bahan dan barang laboratorium. Sebagai contoh misalnya seorang laboran hendak mencari keberadaan alat beban 50 gr maka pada website yang kami rancang, seorang laboran tinggal mengetik nama alat yang dicari dan mengklik tombol search. Website ini dirancang dan dibuat dengan bantuan beberapa dosen pendidikan fisika yang memiliki kemampuan dalam membuat website dengan dukungan dari PUSTIK (Pusat Teknologi Informasi dan Komuniksi) UM Metro.

\section{Pendampingan penggunaan Website}

Website yang telah berhasil dibuat kemudian disosialisasi dan diajarkan kepada guru, laboran dan kepala laboratorium di sekolah mitra. Adapun bentuk uraian kegiataan yang dilakukan dalam penginventaris alat, bahan dan barang laboratorium ke dalam website adalah:

1) Laboran diminta untuk mempersiapkan semua foto alat, barang dan bahan yang ada di dalam laboratorium, dalam pelaksanaanya kami meminta bantuan mahasiswa sedangkan yang melakukan entry data ke website dilakukan oleh laboran sekolah mitra. 
2) Laboran diminta untuk mengisi data diri laboran, dalam menu laboran

3) Pendampingan penggunaan website meliputi: a) Memasukan dan mengedit data alat, bahan maupun barang laboratorium fisika; b) Upload dan menampilkan gambar alat, bahan, barang laboratorium dalam menu utama; c) Mengganti password dan username website; d) Memasukan dan mengedit data diri laboran; e) Memasukan dan mengedit informasi mengenai laboratorium fisika di masing-masing sekolah tersebut.

4) Laboran secara mandiri mencoba melakukan inventaris dengan memasukan data ke website

5) Hasil inventaris yang telah dilakukan laboran akan selalu dipantau oleh tim dosen pengabdi, yaitu dengan melihat perkembangan muatan isi website di masing-masing sekolah mitra sampai dirasa inventaris yang dilakukan telah benar

\section{Pendampingan Penataan ruangan Laboratorium fisika}

Penempatan dan posisi alat yang sesuai akan memudahkan laboran dalam mengambil alat, ataupun bahan yang akan digunakan guru dalam kegiatan praktikum di laboratorium. Adapun tahapan yang dilakukan dalam melakukan setting ruang laboratorium adalah sebagai berikut:

1) Setting ruang.

2) Setting penempatan barang.

3) Pendataan, pengkodean dan penginputan data inventaris ke dalam website.
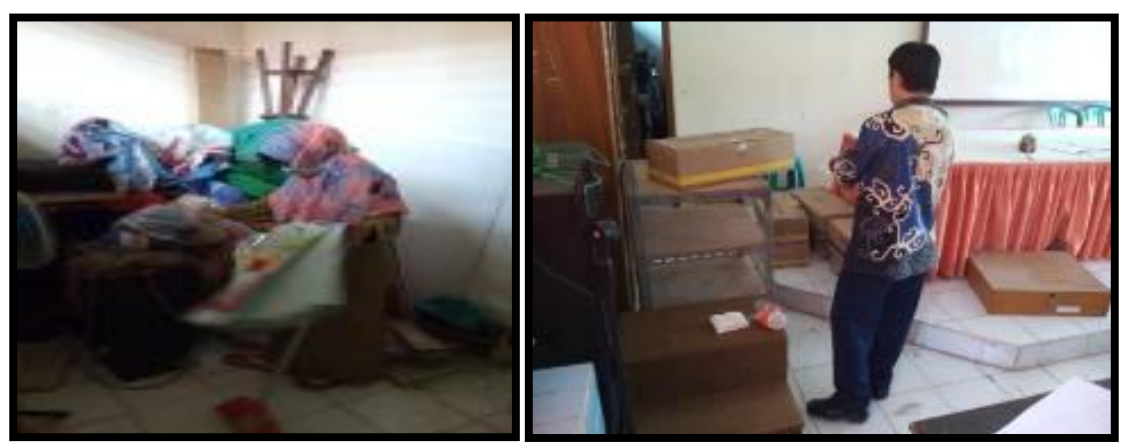

Gambar 2. Aktivitas pendampingan penataan Laboratorium

\section{Sosialisasi Mekanisme Penggunaan Laboratorium}

Setelah alat dan bahan laboratorium diinventaris, diberi label dan ditempatkan pada rak penyimpan dengan kode-kode yang jelas, dan diinput ke 
dalam website inventaris laboratorium sesuai dengan metode, prinsip dan teori yang telah dipelajari, maka selanjutnya diatur dan disusun mekanisme atau SOP penggunaan laboratorium untuk mendukung proses pembelajaran sesuai jadwal pelajaran. SOP dibuat sebagai hasil kerjasama kepala laboratorium fisika dengan dosen pendamping yang kemudian disosialisasikan kepada seluruh dewan guru pengguna laboratorium fisika.

\section{Workshop Program Penggunaan Laboratorium fisika dalam Pembelajaran}

Kegiatan workshop dilakukan untuk menyelaraskan misi mengenai urgensi laboratorium fisika di dalam kegiatan pembelajaran Fisika. Dalam workshop, dewan guru khususnya bidang Fisika diberikan pembekalan mengenai penyusunan panduan praktikum dan tata cara penggunaan dan pelayanan laboratorium. Kegiatan workshop dimulai dari analisis kurikulum untuk mendapatkan mata praktikum yang mungkin dapat dilakukan. Dari berbagai mata praktikum yang akan dilakukan disinkronkan dengan alat dan bahan yang tersedia di laboratorium fisika dan juga memperhatikan jumlah alokasi waktu yang disediakan oleh pengelola laboratorium untuk setiap kelas, sehingga diperoleh sejumlah mata praktikum yang akan dilaksanakan pada semester tersebut. Kegiatan workshop, kemudian dilanjutkan dengan membuat panduan praktikum sesuai dengan alokasi waktu pada jadwal pelajaran yang sudah dibuat. Hasil workshop tersebut kemudian diuji-cobakan pada kelas sesuai dengan SOP pelaksanaan praktikum sesuai jadwal pelajaran di sekolah.
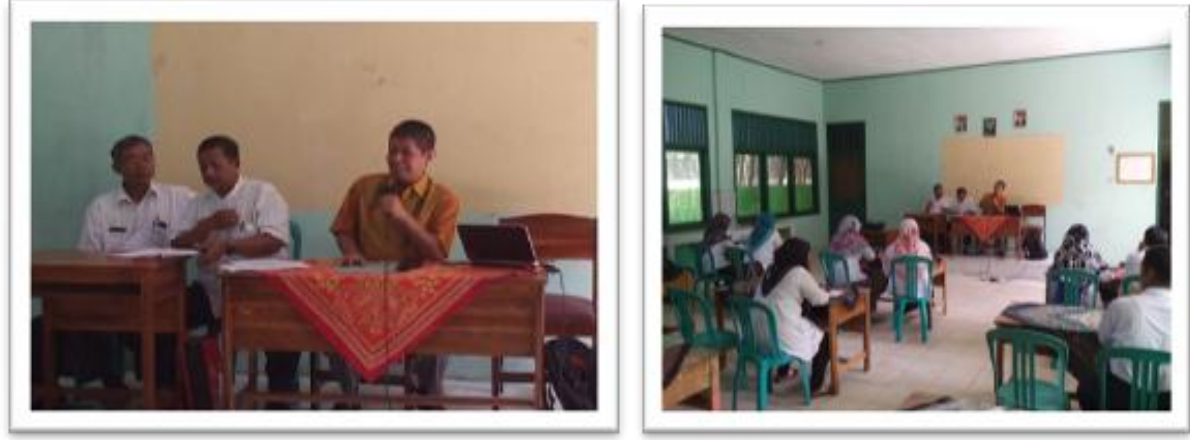

Gambar 3. Sosialisasi penggunaan website inventaris Laboratorium

\section{Program Kegiatan dan Target}

Beberapa kegiatan yang dilakukan dalam pemberdayaan laboratorium fisika dan ketercapaian target diuraikan pada Tabel 1. 
Tabel 2. Kegiatan Bimtek Tenaga Lab, Pendampingan dan Ketercapaian Target

\begin{tabular}{|c|c|c|c|c|}
\hline No & Kegiatan & Sasaran & Target & Data Hasil Kegiatan \\
\hline 1 & $\begin{array}{l}\text { Workshop } \\
\text { menyusun } \\
\text { manual } \\
\text { pengelolaan } \\
\text { Lab } \\
\end{array}$ & $\begin{array}{l}\text { Kepala Lab, } \\
\text { Laboran \& } \\
\text { Guru }\end{array}$ & $\begin{array}{l}\text { Tersusun Manual } \\
\text { pengelolaan Lab } \\
\text { Fisika }\end{array}$ & $\begin{array}{l}\text { Manual pengelolaan Lab SMAN } \\
1 \text { Metro, SMAN } 2 \text { Metro dan } \\
\text { SMAN } 5 \text { Metro terwujud. telah } \\
\text { diperiksa waka kurikulum serta } \\
\text { disahkan oleh Kepala Sekolah }\end{array}$ \\
\hline 2. & $\begin{array}{l}\text { Melakukan } \\
\text { Inventaris, } \\
\text { labeling } \\
\text { dan } \\
\text { penyusuna } \\
\text { n Alat dan } \\
\text { bahan Lab }\end{array}$ & Laboran & $\begin{array}{l}\text { Sarana-prasarana } \\
\text { Lab, serta Alat dan } \\
\text { bahan Lab } \\
\text { teridentifikasi baik } \\
\text { jumlah, jenis dan } \\
\text { kondisinya, serta } \\
\text { tersusun rapih }\end{array}$ & $\begin{array}{l}\text { Tersusun data inventaris alat, } \\
\text { bahan dan barang di sekolah } \\
\text { mitra }\end{array}$ \\
\hline 2 & $\begin{array}{l}\text { Pembuatan } \\
\text { denah } \\
\text { laboratorium }\end{array}$ & Laboran & $\begin{array}{l}\text { Penempatan dan } \\
\text { penyusunan alat, } \\
\text { bahan, dan barang } \\
\text { yang strategis }\end{array}$ & $\begin{array}{l}\text { Denah ruang laboratorium di } \\
\text { sekolah mitra, terbentuknya } \\
\text { sistem pengkodean alat, bahan } \\
\text { dan barang laboratorium di } \\
\text { sekolah mitra }\end{array}$ \\
\hline 3 & $\begin{array}{l}\text { Pembuatan } \\
\text { Website } \\
\text { Inventaris } \\
\text { Laboratorium }\end{array}$ & $\begin{array}{l}\text { Kepala Lab, } \\
\text { Laboran \& } \\
\text { Guru }\end{array}$ & $\begin{array}{l}\text { Terinventarisnya } \\
\text { seluruh fasilitas } \\
\text { laboratorium ke dalam } \\
\text { website }\end{array}$ & $\begin{array}{l}\text { Inventaris alat dan bahan } \\
\text { laboratorium ke dalam website } \\
\text { SMAN } 2 \text { Metro dan SMAN } 5 \\
\text { Metro dengan link alamatnya: } \\
\text { http://laboratorium.sman2metro } \\
\text {.sch.id. } \\
\text { Sedangkan untuk SMAN } 1 \\
\text { Metro masih dalam proses } \\
\text { pengerjaan dan perbaikan } \\
\text { website (localhosting) }\end{array}$ \\
\hline 4. & $\begin{array}{l}\text { Pembuatan } \\
\text { Program } \\
\text { Kerja Lab }\end{array}$ & $\begin{array}{l}\text { Kepala } \\
\text { Sekolah, } \\
\text { Kepala Lab, } \\
\text { Laboran dan } \\
\text { Guru Fisika }\end{array}$ & $\begin{array}{l}\text { Terbentuk program } \\
\text { kerja semester dan } \\
\text { tahunan yang sesuai } \\
\text { kondisi dan } \\
\text { kebutuhan sekolah }\end{array}$ & $\begin{array}{l}\text { Program kerja semester dan } \\
\text { Tahunan SMAN } 2 \text { Metro } \\
\text { terwujud dan telah disahkan } \\
\text { Kepala Sekolah, Sedangkan } \\
\text { untuk SMAN } 1 \text { Metro dan } \\
\text { SMAN } 5 \text { Metro sedang dalam } \\
\text { proses dan akan diwujudkan } \\
\text { pada tahun ajaran berikutnya. }\end{array}$ \\
\hline 5. & $\begin{array}{l}\text { Uji coba } \\
\text { Penggunaa } \\
\text { n Lab }\end{array}$ & $\begin{array}{l}\text { Kepala } \\
\text { Sekolah, } \\
\text { Kepala Lab, } \\
\text { Laboran, } \\
\text { Guru Fisika } \\
\text { dan Siswa }\end{array}$ & $\begin{array}{l}\text { Kegiatan praktikum di } \\
\text { laboratorium fisika } \\
\text { terlaksana sesuai } \\
\text { jadwal pelajaran } \\
\text { Fisika, tanpa } \\
\text { mengganggu mata } \\
\text { pelajaran lain }\end{array}$ & $\begin{array}{l}\text { Dihasilkan dokumen: } \\
\text { 1) SOP praktikum sesuai jadwal } \\
\text { pelajaran } \\
\text { 2) Jadwal kegiatan praktikum } \\
\text { 3) Tata tertib siswa dan guru } \\
\text { dalam penggunaan lab Fisika }\end{array}$ \\
\hline
\end{tabular}




\section{Peningkatan kondisi Laboratorium fisika}

Setelah dilakukan program Bimtek tenaga laboratorium dan pendampingan dalam memberdayakan laboratorium fisika, maka kondisi laboratorium fisika sebelum dan sesudah diberi perlakuan dapat dikemukakan pada Tabel 3.

Tabel 3. Kondisi Laboratorium fisika sebelum dan Sesudah Kegiatan

\begin{tabular}{|c|c|c|c|}
\hline No. & Kondisi Sebelum & Kondisi Sesudah & Peningkatan \\
\hline 1 & $\begin{array}{l}\text { Aspek SDM } \\
\text { Tenaga Lab Fisika terdiri } \\
\text { dari Kepala Lab dan } \\
\text { Laboran (pengetahuan } \\
\text { tentang pengelolaan lab } \\
\text { masih minim/ tidak } \\
\text { bersertifikat) }\end{array}$ & $\begin{array}{l}\text { Tenaga Lab terdiri dari } \\
\text { Kepala Lab dan Laboran } \\
\text { yang mengetahui tugas } \\
\text { pokok dan fungsinya serta } \\
\text { menguasai ilmu pengelolaan } \\
\text { lab }\end{array}$ & $\begin{array}{l}\text { Kemampuan Tenaga Lab } \\
\text { Meningkat (bersertifikat). }\end{array}$ \\
\hline 2. & $\begin{array}{l}\text { Aspek Sarpras \& alat-bahan } \\
\text { Lab } \\
\text { Sarana, alat dan bahan } \\
\text { praktikum Lab lengkap, } \\
\text { tetapi belum tersusun dan } \\
\text { terinventaris dengan baik, } \\
\text { serta jumlah dan kondisi alat } \\
\text { belum diketahui. }\end{array}$ & $\begin{array}{l}\text { Sarana, alat dan bahan } \\
\text { praktikum lab lengkap, sudah } \\
\text { tersusun rapi dan } \\
\text { terinventaris dengan jelas, } \\
\text { baik jumlah maupun } \\
\text { tempatnya. Serta sebagian } \\
\text { besar sudah terinventaris } \\
\text { pada website }\end{array}$ & $\begin{array}{l}\text { Sarana, alat dan bahan lab } \\
\text { tersusun rapi dan semua } \\
\text { telah terinventaris, serta } \\
\text { jenis dan jumlah serta } \\
\text { kondisi alat lab yang } \\
\text { dimiliki SMAN 2Metro, } \\
\text { SMAN } 1 \text { Metro dan SMAN } \\
5 \text { Metro diketahui dengan } \\
\text { jelas. }\end{array}$ \\
\hline 3. & $\begin{array}{l}\text { Aspek Manajemen Lab } \\
\text { Belum ada manual } \\
\text { pengelolaan Lab dan } \\
\text { tupoksi Tenaga lab }\end{array}$ & $\begin{array}{l}\text { Tersusun manual pengelolan } \\
\text { lab dan tupoksi masing- } \\
\text { masing tenaga lab }\end{array}$ & $\begin{array}{l}\text { Sistem pengelolaan lab } \\
\text { dan tupoksi masing-masing } \\
\text { tenaga lab jelas }\end{array}$ \\
\hline 4. & $\begin{array}{l}\text { Aspek Program \& Kegiatan } \\
\text { Lab } \\
\text { Terdapat program kerja lab } \\
\text { tiap semester dan tahunan. } \\
\text { Tetapi tidak berjalan, karena } \\
\text { program kerja dibuat oleh } \\
\text { tenaga laboratorium dan } \\
\text { belum ada mekanisme kerja } \\
\text { team antara guru, kepala lab } \\
\text { dan laboran. }\end{array}$ & $\begin{array}{l}\text { Program kerja Lab dibuat } \\
\text { secara team melalui } \\
\text { mekanisme kerja yang jelas } \\
\text { dan dituangkan dalam SOP. } \\
\text { Karena kapasitas dan } \\
\text { subtansi praktikum disusun } \\
\text { berdasarkan analisis situasi } \\
\text { dan kondisi, maka program } \\
\text { kerja lebih realistis dan dapat } \\
\text { dilaksanakan dengan baik. }\end{array}$ & $\begin{array}{l}\text { Program kegiatan } \\
\text { praktikum sesuai dengan } \\
\text { kapasitas laboratorium } \\
\text { fisika setiap semester, } \\
\text { sehingga kegiatan } \\
\text { praktikum di Lab } \\
\text { Fisikasebanyakmata } \\
\text { praktikum tiap semester, } \\
\text { sehingga rata-rata kegiatan } \\
\text { praktikum di Lab Fisika } \\
\text { sebanyak } 3 \text { kali tiap hari }\end{array}$ \\
\hline
\end{tabular}

\section{SIMPULAN}

Berdasarkan hasil dan pembahasan yang telah dikemukakan di atas, maka dapat dikemukakan beberapa kesimpulan: 1) Adanya website inventaris laboratorium sangat membantu guru dan laboran dalam mengadministrasi dan 
melakukan pelacakan alat, bahan, maupun barang laboratorium. 2) Laboratorium fisika di Kota Metro dapat dimanfaatkan dalam menunjang proses pembelajaran Fisika secara efektif, setelah manajemen dan administrasi laboratorium disusun sedemikian rupa sehingga memudahkan guru dan siswa dalam kegiatan praktikum.

\section{REFERENSI}

Peraturan Menteri Pendidikan Nasional Republik Indonesia Nomor 26 Tahun 2008 tentang Standar Tenaga Laboratorium Sekolah/Madrasah.

Peraturan Pemerintah Republik Indonesia Nomor 19 Tahun 2005 tentang Standar Pendidikan.

Suseno, N. et al. (2014). Buku panduan kepala laboratorium sekolah/madrasah. Kota Metro: Lembaga Penelitian UM Metro Press.

Suseno, N. (2012). Peran praktikum dalam mengembangkan kemampuan dan karakter mahasiswa calon guru fisika pada mata kuliah keahlian program studi (Studi kasus pada perkuliahan elektronika dan listrik magnet). In Tim Lesson Studi (Eds.), Membangun karakter guru dan dosen untuk mewujudkan pendidikan berkarakter. Paper presented at Seminar Nasional Pendidikan ke-1, Universitas Muhammadiyah Metro, Metro, November 2012 (pp. 132 -139). Metro: Tim Lesson Studi FKIP UM Metro.

Suseno, N., Partono, \& Harjati, P. (2011). Memadukan alat peraga dan analogi sebagai upaya menerapkan inkuiri dalam pembelajaran konsep abstrak fisika. Jurnal Nuansa Pendidikan, 15(1), 1-8.

Yolanda, B., Tapillow, F. S., \& Wulan, A. R. (2011). Implementasi pembelajaran berbasis praktikum pada pembelajaran konsep metabolisme untuk meningkatkan kemampuan berpikir kritis. Jurnal Pendidikan MIPA, 12(1), 59-66. 